\title{
Utilization of Natural Zeolite from Ponorogo and Purworejo for Naphthol Substance Adsorption
}

\author{
Sundus Imandiani ${ }^{1,{ }^{*}}$, Christine Indira ${ }^{1}$, Anthony Johan $^{1}$ and Budiyono ${ }^{1}$ \\ ${ }^{1}$ Department of Chemical Engineering, Faculty of Engineering, Diponegoro University, Semarang - Indonesia
}

\begin{abstract}
Indonesia has many zeolite producing areas yet untapped. Researchers developed the utilization of natural zeolites useful for the adsorption of naphthol dyes commonly found in batik waste. In this study researchers used natural zeolites from Purworejo and Ponorogo that are activated using hydrochloric acid that is used for adsorption. The purpose of this research is to know the effect of natural zeolite activation from Ponorogo and Purworejo on the effectiveness of adsorption of naphthol dyes widely used in batik industry. Natural zeolite was activated using $\mathrm{HCl}$ concentration of $1.3 \mathrm{~N} ; 1.8 \mathrm{~N} ; 3.2 \mathrm{~N}$; and $3.9 \mathrm{~N}$ for 60 minutes. The methods are preparation of natural zeolite from Purworejo and Ponorogo, dealumination using hydrochloric acid, adsorption process of naphthol dyes using activated zeolite, and test of adsorption result with uv-vis spectrophotometry. The test results showed that the higher $\mathrm{HCl}$ concentration will increase adsorption capacity. This can be known from the concentration of naphthol dye which decreased both using natural zeolite Ponorogo and Purworejo. While the effectiveness of adsorption shows natural zeolite Purworejo has a greater adsorption capacity than Ponorogo with optimum conditions of dealumination using concentration $\mathrm{HCl} 3,9 \mathrm{~N}$.
\end{abstract}

\section{Introduction}

One of the most developed industries in Indonesia is batik industry. Batik industry in 2006 amounted to 48,287 business units spread over 17 provinces, and employed 792,300 people [1]. The main source of waste in the batik industry is dyes, which are contain naphthol dyes. If the waste is continuously discharged directly into the waters and exceeds the ability of the river to clean themselves (self-purification), there will be pollution of the waters that negatively affect the life of aquatic biota and public health utilizing the river water.

Natural zeolite is a group of minerals produced from hydrothermal processes in alkaline igneous rocks, and is a precipitate of volcanic activity which contains many silica elements [2]. Zeolite crystals are very regular with interconnected cavities in all directions and make the zeolite surface area so large that it is very well used as an adsorbent [3]. The composition of natural zeolite varies greatly, depending on the species. Zeolites occur naturally on the soil surface. Today many types of natural zeolites have been found and grouped by their structural similarity. Although synthetic zeolites have also been produced, natural zeolites have an important role because of their abundant availability in nature, especially in Indonesia.

In contrast to synthetic zeolites whose predictable structure of their constituent compounds, natural zeolites have structures that are not always the same, depending on the conditions of their formation in nature. Therefore, in the use of natural zeolite as an adsorbent, the activation process is required. This activation process is needed to improve the specific properties of zeolites and remove impurities. In this research used dealumination method with $\mathrm{HCl}$.

The purpose of this study is to examine the effect of $\mathrm{HCl}$ concentration in the zeolite adsorbent activation process on the effectiveness of naphthol adsorption dyes

\section{Methods}

\subsection{Preparation and Activation}

Natural zeolites that have been obtained from Ponorogo and Purworejo are smoothed to a size of 100 mesh, then zeolite washed with demineralized water and dried using oven to constant weight.

The process of activating the natural zeolite was carried out using $\mathrm{HCl}$ solution. Zeolite as much as 100 and 10 gram mixed for 60 minutes with $\mathrm{HCl}$ solution with concentration of $1.3 \mathrm{~N} ; 1,8 \mathrm{~N} ; 3,2 \mathrm{~N} ; 3,9 \mathrm{~N}$ as much as $100 \mathrm{ml}$, then filtered. The zeolite precipitate is then dried with oven to constant weight.

\subsection{Adsorption Process}

In the adsorption process, 10 grams of natural zeolite was mixed with naphthol dye with a concentration of $400 \mathrm{ppm}, 600 \mathrm{ppm}, 800 \mathrm{ppm}$, and $1000 \mathrm{ppm}$ of $100 \mathrm{ml}$

\footnotetext{
"Corresponding author: christineindirarinai@gmail.com
} 
with constant stirring. After that the solution was filtered to separate the filtrate, then the filtrate was measured its absorbance by UV-VIS Spectrophotometer, then calculated the final concentration of the naphthol dye after adsorption process.

\section{Results And Discussion}

\subsection{Naphthol Dye Adsorption Test}

The naphthol absorption analysis was carried out based on absorbed concentration, and absorption percentage. From the dealumination process that has been done on zeolite from Ponorogo (ZAP) and Purworejo (ZAW) using $\mathrm{HCl}$ solution with concentration of $1.3 \mathrm{~N} ; 1.8 \mathrm{~N}$; $3.2 \mathrm{~N}$; and $3.9 \mathrm{~N}$. Natural zeolite then used as a naphthol dye adsorbent at various concentrations of $400 \mathrm{ppm}, 600 \mathrm{ppm}, 800 \mathrm{ppm}$ and $1000 \mathrm{ppm}$. The final concentration of the solution after the adsorption process presented in Figure 1 and Figure 2.

Based on Figures 1 and 2 showing the zeolite dealumination process with a concentration of $3.9 \mathrm{~N}$ $\mathrm{HCl}$ solution gives the best possible adsorption results with the final concentration of the least naphthol dye with an average percentage of naphthol dye absorbed up to $98.61 \%$ in the natural zeolite Ponorogo And $98.92 \%$ in natural zeolite Purworejo.

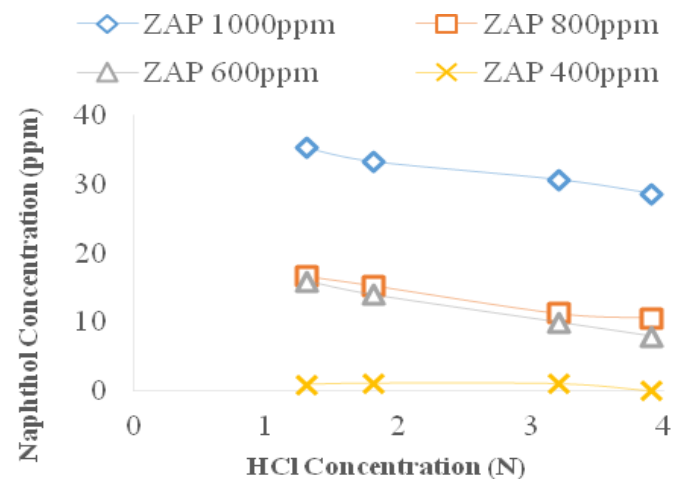

Fig. 1. Naphthol Concentration after Adsorption (ZAP)

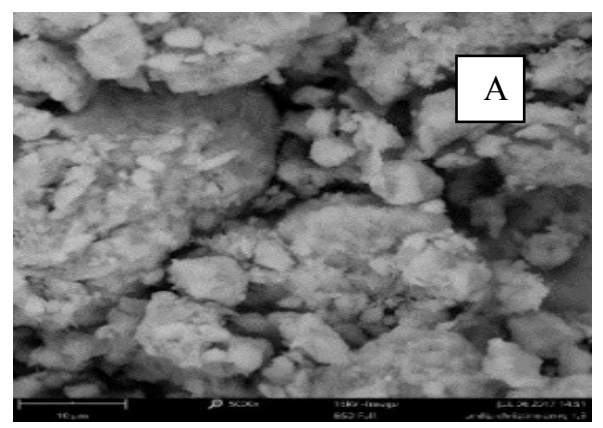

The amount of adsorbed naphthol dye stuff indicates an increase in surface area in activated natural zeolites. The completion of the dealumination process will cause the rise of zeolite surface area due to the reduction of impurity metal covering the pores of the zeolite with the increase of surface area will result in the absorption process happening the greater [4].

While activation of natural zeolite with $\mathrm{HCl}$ concentration solution $3,2 \mathrm{~N} ; 1.8 \mathrm{~N}$; and $1.3 \mathrm{~N}$ continue to decrease with the smaller concentration of $\mathrm{HCl}$ solution used, the average percentage of the least absorbed naphthol dyestuff is by the activation treatment at $\mathrm{HCl} 1.3 \mathrm{~N}$ solution concentration of $97.8 \%$ for Ponorogo zeolite and 98 \% For Purworejo zeolite. This is because the natural zeolite still contains many impurities that cover the zeolite surface and also because the natural zeolite has not formed silanol group due to activation with acid so that adsorption is less effective.

SEM Characteristic show the difference of natural zeolite particle size before and after activation, using $\mathrm{HCl} 3,9 \mathrm{~N}$. The particle size of natural zeolite before activation is $2,41 \mu \mathrm{m}$, while after activated using HCL the particle size changes to smaller that is $0,5-0,8 \mathrm{~mm}$ as presented in Figure 3. The smaller particle size will increased the surface area of zeolite and make the adsorption process better.

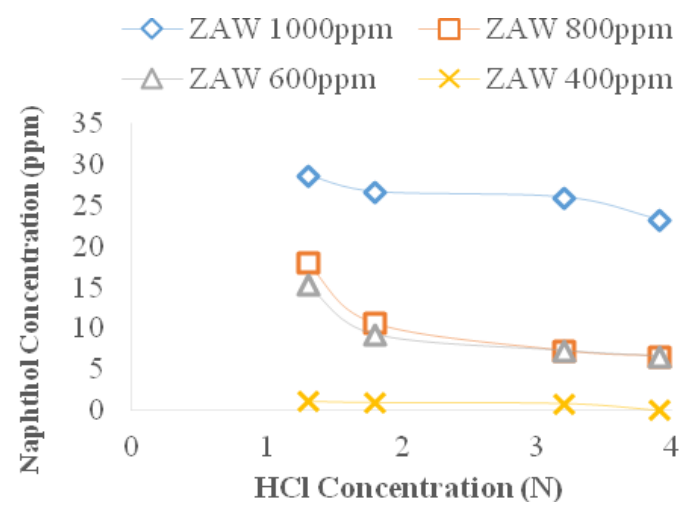

Fig. 2. Naphthol Concentration after Adsorption (ZAW)

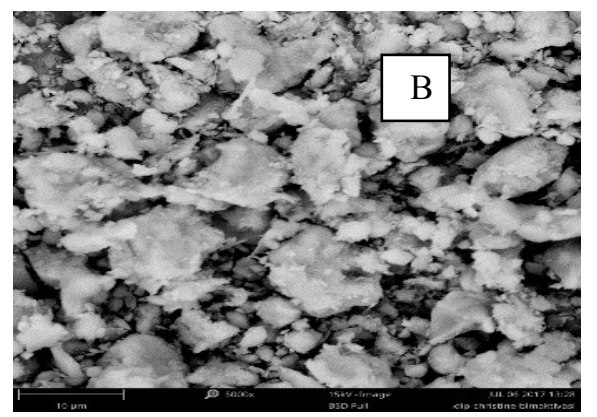

Fig. 3. SEM Characteristic on ZAP before Activation (A); ZAP after Activation (B) 


\subsection{Zeolite Dealumination}

EDX test results show the composition of natural zeolite from Ponorogo and Purworejo that are activated using hydrochloric acid solution $3.9 \mathrm{~N}$.

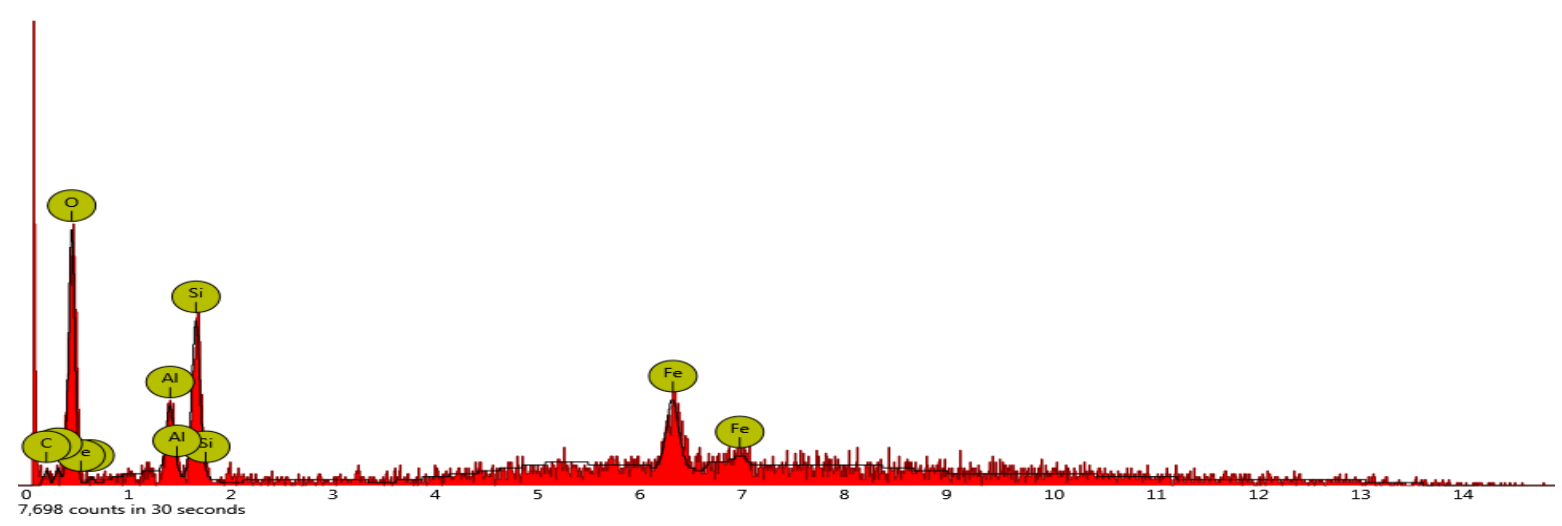

Fig. 4. EDX Analys is on Activated Natural Zeolite from Ponorogo

Table 1. Ponorogo Natural Zeolite (ZAP) Composition

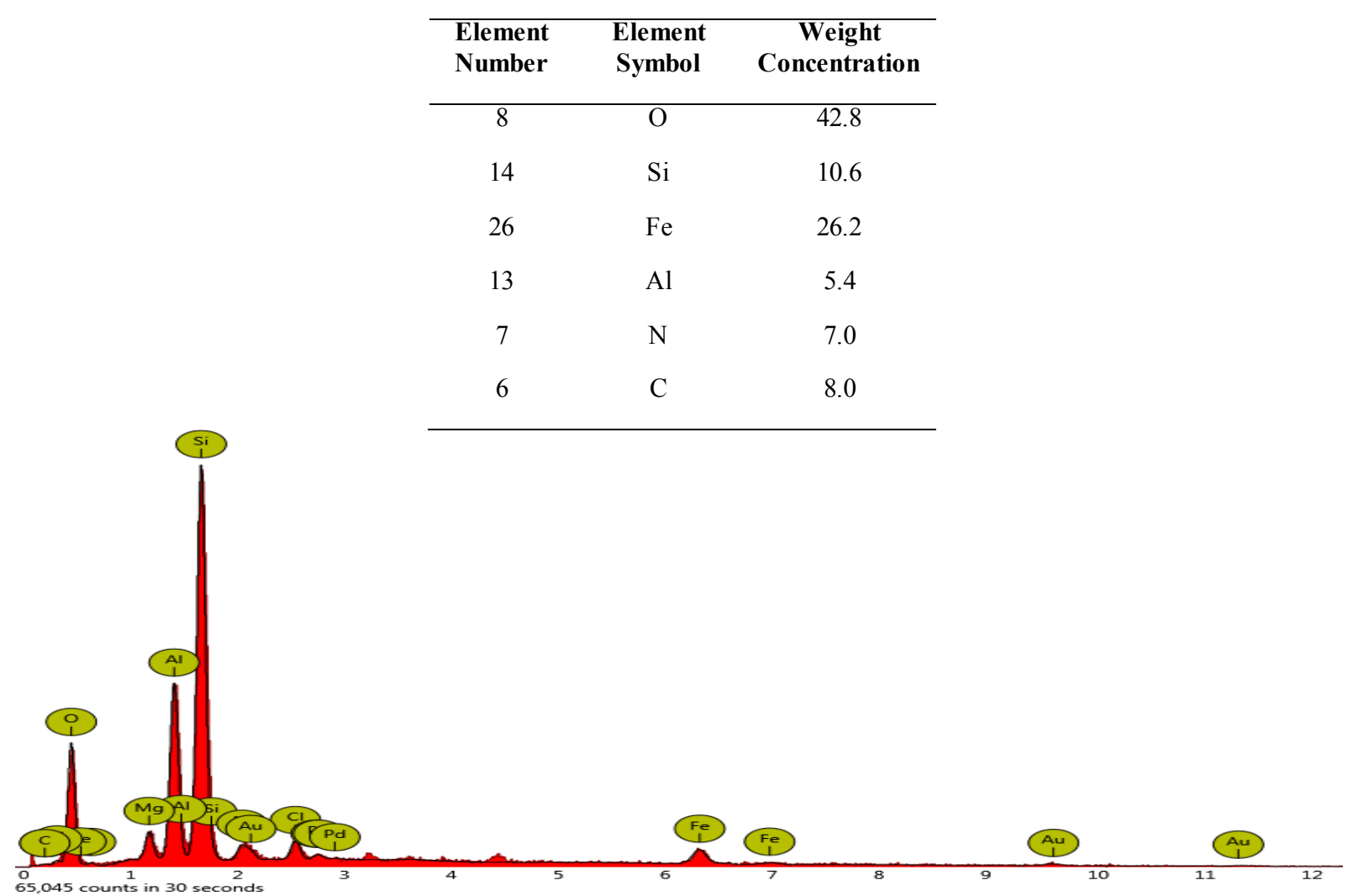

Fig. 5. EDX Analys is on Activated Natural Zeolite from Purwoerjo 
Table 2. Purworejo Natural Zeolite (ZAW) Composition

\begin{tabular}{ccc}
\hline $\begin{array}{c}\text { Element } \\
\text { Number }\end{array}$ & $\begin{array}{c}\text { Element } \\
\text { Symbol }\end{array}$ & $\begin{array}{c}\text { Weight } \\
\text { Concentration }\end{array}$ \\
\hline 14 & $\mathrm{Si}$ & 5.3 \\
13 & $\mathrm{Al}$ & 2.6 \\
8 & $\mathrm{O}$ & 7.1 \\
12 & $\mathrm{Mg}$ & 0.5 \\
17 & $\mathrm{Cl}$ & 0.5 \\
26 & $\mathrm{Fe}$ & 1.0 \\
46 & $\mathrm{Pd}$ & 0.4 \\
7 & $\mathrm{~N}$ & 0.6 \\
79 & $\mathrm{Au}$ & 81.8 \\
6 & $\mathrm{C}$ & 0.2 \\
\hline
\end{tabular}

From the analysis it can be seen the ratio of $\mathrm{Si} / \mathrm{Al}$ on ponorogo zeolite is 2 and zeolite Purworejo is 2.04 . So the result of adsorption between natural zeolite Ponorogo and Purworejo are not much different.

The influence of $\mathrm{Si} / \mathrm{Al}$ ratio on a material will affect the properties of the material. The higher the $\mathrm{Si} /$ $\mathrm{Al}$ ratio of a material the material is hydrophobic. Dealumination is the most important commercial method of getting the desired amount of Al. An increase in $\mathrm{Si} / \mathrm{Al}$ ratio will cause changes in the electrostatic magnetic field in the zeolite, thus affecting the interaction of zeolite adsorption [1].

The accumulation of natural zeolite as aluminosilicate with $\mathrm{HCl}$ can be seen as a process of replacing aluminum with hydrogen which involves altering the structure of Si-O-Al aluminosilicate into a silica structure in the form of silanol -Si-OH group ${ }^{1}$. The greater the concentration of $\mathrm{HCl}$ used to activate the zeolite causes the crystallinity of the zeolite to be relatively decreased. This is due to the increase in $\mathrm{HCl}$ concentration which is getting bigger and causing the dealumination ( $\mathrm{Al}$ out of the zeolite framework) more and more. With the escalation of $\mathrm{Al}$ atoms more and more zeolites cause decrystallization which will lead to increased irregular crystal structure resulting in less [5].

\section{Conclusions}

The activation process performed on both zeolites derived from ponorogo and purworejo showed that with the increased $\mathrm{HCl}$ concentration used, the ability of adsorption in natural zeolites increased. It is indicated by the percentage of adsorbed naphthol concentration. The activation process using $\mathrm{HCl}$ causes the $\mathrm{Si} / \mathrm{Al}$ ratio on the zeolite to increase. And also causes the pore surface area of zeolite to increase due to the loss of impurity components in the zeolite

\section{References}

1. Ranjani V.Siriwardane, Ming-Shin Shen, and Edward P. Fisher, Adsorption Of $\mathrm{CO}_{2}, \mathrm{~N}_{2}$, and $\mathrm{O}_{2}$ on Natural Zeolit, West Virginia 26507-0880. (2002).

2. Wang, Shaobin and Peng, Yuelian. Natural Zeolites as Effective Adsorbents in Water and Wastewater Treatment. Department of Engineering, Curtin University of Technology, (2009)

3. 2 A. Ertan, and Ozkan. Adsorption, Vol 11, 151 156, (2005)

4. Worch. Eckhard, Adsorption Technology in Water Treatment, Dresden Germany, (2012).

5. Eunjoo Kim et al, Mono-dispersed DDR Zeolit Particles by seeded Growth and their $\mathrm{CO}_{2}, \mathrm{~N}_{2}$, and $\mathrm{H}_{2} \mathrm{O}$ Adsorption Properties (2016).

6. Benefield. Process Chemistry for Water and Waste Water Treatment. Prentice Hall Inc: New Jersey, 1982 